Volume 7 Issue 2, June 2020

Nationally Accredited Journal,

Decree No. B/4130/E5/E5.2.1/2019

\title{
Notary Role In Making The Deed Of Murabahah Financing On Islamic Bank (Review On Financing Agreement In Islamic Bank Of Central Java)
}

\begin{abstract}
Anindia Inka Saputri ${ }^{1}$, Agus Supriadi ${ }^{2}$ and Aryani Witasari ${ }^{3}$
Abstract. This study aims to determine the form of the contract and Murabahah financing mechanisms, to analyze the application of Sharia principles in Murabahah financing agreement, and to know the extent to which the role of the Notary in the Deed manufacture Murabahah Financing Agreement with Islamic Bank of Central Java. The results of this study show that: (1) The form of contract and Murabahah financing mechanism in Islamic Bank of Central Java refers to the provisions of Islamic Banking Act, BI (Bank Indonesia), FSA (Financial Services Authority) and DSN-MUI. (2) The application of Islamic principles in the financing agreement Murabahah in Bank Central Java Sharia has been in accordance with the Law of Islamic Banking and DSN-MUI, where financing based on Islamic principles that do not contain elements of usury, gambling, Garar, illegitimate and unjust.
\end{abstract}

Keywords: Notary; Islamic Banking; Murabahah.

\section{Introduction}

Notary is a public official authorized to make an authentic deed of the extent to which certain authentic deed is not reserved for other public officials. Making the authentic deed stipulated in Act invitation in order to create certainty, order and legal protection. Notary ensure certainty about the date, save the deed and give groose, copies and excerpts, all along the deed was by a general rule not also be assigned or excluded to the officer or others. ${ }^{4}$

Notary create authentic act which is the strongest proof tool with an important role in any legal relations in society. In a variety of business relationships, banking, social activities, and others, the need for written evidence in the form of an authentic deed is increasing in line with increasing demand for legal certainty in various economic and social activities, both at national and international level. With the authentic deeds, provide legal certainty to the holder, and to avoid disputes at a later date, although in case the dispute can not be avoided, the authentic act is written evidence of the strongest in the dispute resolution process. ${ }^{5}$

The position of notaries as public officials such as the purpose of the provisions of Notary Law (UUJN) No. 30 of 2004 is a title awarded by the state symbolically. In accordance with the provisions of Article 2 UUJN, namely a notary appointed and dismissed by the Minister of State. Minister of state mean that the Minister of Justice (now called Menkumham), then a notary can carry out their duties freely without being influenced by the executive bodies or elements of some other government body. The

\footnotetext{
${ }^{1}$ Student Master of Notary Program, Faculty of Law, Sultan Agung Islamic University, email: inkadea@gmail.com

${ }^{2}$ Student of Master of Law Program, Faculty of Law, Universitas Islam Sultan Agung email agussupriadi.ptik68@gmail.com

${ }^{3}$ Lecturer of Master of Law, Sultan Agung Islamic University (UNISSULA), Semarang

${ }^{4}$ Laurencius Arliman S, 2015, Notaris dan Penegak Hukum Oleh Hakim, Deepublish, Yogyakarta, p.2

${ }^{5}$ Elucidation of Act No. 30 of 2004 on Notary
} 
point is that a notary will not be afraid to carry out his duties, so that it can act in a neutral and independent. ${ }^{6}$

Notary public demand for and the deed which made progressing more rapidly, now has greater awareness of Community law in conducting their legal relations, one of the legal relationships in the banking sector, which can not be separated from Notary services.

In the banking sector in Indonesia, the notary has an important role in the growth of Islamic Financial Institutions (LKS) is rapidly increasing. Notary has the authority to make agreements and determination are required by law or by the interested public as well as desired to be stated in an authentic deed. Thus ensuring the deed certainty and does not cause problems or disputes in the future. Datas on time, deposit certificates, copies and excerpts and others, throughout the deed was stipulated by a general rule, and also assigned or excluded to the officer or others. ${ }^{7}$

However, there is no legislation that explicitly and in detail discuss specifics regarding notary sharia, but in all the practices in Islamic banking business agreement has had its own legislation. For example, there is a provision in Article 17 point 1 (i) Act No. 2 of 2014 On Notary which provides that "Notaries are prohibited from doing other work that is contrary to the norms of religion, morality, and decency that may affect the honor and dignity of the office Notary Public".

Formally, the legal provisions in Article 17 point 1 (i) Act No. 2 of 2014 On Notary mentioned above is not set up at all the presence of a notary sharia, although not strictly regulated, but the article is seen as a starting point the opening of spacerelated the presence of a notary sharia. At present, procedures that allow a notary sharia to be recognized legally, he should follow some of the certification process with integrated training with the Indonesian Notary Association (INI), one certification program in collaboration with the Indonesian Banking Development Institute and the International Center for Development in Islamic Finance (ICDIF ) or also Iqtishad Consulting (IC).

The existence of Islamic Banking, cause a variety of reactions in the community, which assumes no Islamic banking is seen as emotionally self-rescue-ideological, not rescue (solution) from economic problems. They argue that Islamic banks are conventional banks with terms of banking using Islamic terms, as in the execution of the contract in Islamic banks are still using ways that are prohibited by religion. That is one form of the attitude of society that the Islamic banking because it can not be denied that the connotations of banking since the first was distinctly separated by sharia so at the beginning of the establishment of Islamic banking many who do not believe in the success of Islamic economists in bringing together the banking institutions with Shariah , Agreement lot of judgments about the implementation of halal is Murabahah, ie purchase with a sales price consists of the purchase price and the agreed profit. This is because there are misperceptions on Murabahah contract. Murabahah is often equated with ordinary credit agreements, only the name was changed Murabahah or purchase. In fact, besides the price is more expensive than the price on the loan application in conventional banks, and also the implementation procedure looks no difference between Murabahah with conventional banking credit. Murabahah is often equated with ordinary credit agreements, only the name was changed Murabahah or purchase. In fact, besides the price is more expensive than the price on the loan application in

\footnotetext{
${ }^{6}$ Dedy Rajasa Waluyo, 2013, Hanya Ada Satu Pejabat Umum Ialah Notaris, Notary Journal, Bandung, (Yuspin, 2007) p. 41.

${ }^{7}$ Laurencius Arliman S, loc. cit.
} 
Volume 7 Issue 2, June 2020

Nationally Accredited Journal,

Decree No. B/4130/E5/E5.2.1/2019

conventional banks, and also the implementation procedure looks no difference between Murabahah with conventional banking credit. Murabahah is often equated with ordinary credit agreements, only the name was changed Murabahah or purchase. In fact, besides the price is more expensive than the price on the loan application in conventional banks, and also the implementation procedure looks no difference between Murabahah with conventional banking credit. ${ }^{8}$

In UUJN not know their beliefs with regard to the religious affiliation of the parties are to be made to Notary deed. Although BLM retains sharia principles, namely the principles of Islamic law in banking activities by the fatwa issued by the institution that has the authority in setting the fatwa in the field of sharia, ${ }^{9}$ but interacting with LKS not only Muslims, but also the public at large. Accordingly, this study aims to determine: The form of financing in Islamic Bank; Murabahah Financing Process in Islamic Bank of Central Java as well as the role of the Notary in the Deed of Murabahah manufacture in Islamic Bank of Central Java?

\section{Research methods}

This study was conducted using the method of Empirical Approach (sociological) drawn from the facts in the public relations, and legal entities, which in the formulation and discussion of the problem is qualitative (not shaped figure). Specifications research is using descriptive analysis aims to describe or depict and analyze the data obtained in a systematic, factual and accurate, including the legislation in force associated with legal theories and practice of positive law concerning the above problems, The research location is at Islamic Bank-Semarang,Central Java with research methods is by way of a field study (primary) and the study of literature (secondary). Field studies (primary) form of observations and interviews, which the way of guided interview as individual and discussion.

\section{Results and Discussion}

\subsection{Form of Islamic Bank Financing}

In general, Islamic Banking consists of three categories, differentiated by the intended use, namely:

- Financing with the principle of trading is intended to have the goods to the level specified in the initial bank profit (margin), this loan product consists on Murabahah, greetings, and istishna.

- Financing lease principle is intended to get the services of the bank profit rate is determined at the outset, this financing product consists of Ijara and IMTB.

- Financing with the principle of sharing is used for cooperative efforts aimed to obtain goods and services at once, with the level of bank profits are determined by the amount of business profit in accordance with the principle of sharing, in this financing profit sharing is determined by the profit sharing ratio agreed in early as in the Musharakah and Mudarabah contract.

\footnotetext{
${ }^{8}$ Wardah Yuspin 2007, Penerapan Prinsip Sharia dalam Pelaksanaan Akad Murabahah, Journal of Legal Studies Vol. 10, Surakarta, No.1, p. 55-67

${ }^{9}$ Based on Article 1 paragraph 7 of Act No. 21 of 2008 on Islamic Banking, Islamic Banking is the Bank's definition of running their business based on Sharia Principles and by type consisting of Islamic Banks and Islamic Bank Financing.
} 


\subsection{Murabahah Financing Process in Islamic Bank of Central Java}

One of the products that use the Bank of Central Java Islamic Murabahah financing agreement is IB Griya, the principle of trading where the sale price is set based on the purchase price plus profit that has been agreed upon. Financing implementation procedures Griya iB of Islamic Bank of Central Java is when the customer wants to buy a house on the developer or individual but the client does not have the funds mencukupimaka customers come to the Java Islamic Bank for filing finance home purchases.

Procedure clients apply Sharia financing at Bank of Central Java are:

\subsubsection{Requirements :}

- Indonesian citizens.

- Individuals (not businesses).

- Minimum age 21 years filing financing.

- Having a regular income or sustainable.

- Funding Request Form Filling Griya iB Bank of Central Java.

- Completing the required documents.

2.2.2.Scheme funding application process. Acceptance of the financing request from prospective customers: ${ }^{10}$

- Applicant came to the bank clerk who handles the financing for information on financing provided by Bank. Subsequently, the clerk will give an explanation of the requirements of the provision of financing to be filed.

- Customers fill out their own form petition containing about Applicant Name, address, mother's maiden name, type of business, type of financing proposed, Nominal petition, intended use, Timed.

- Thereafter, a request form signed by the applicant and should be given when the company stamp-shaped Enterprises. If the petition form has been completed, a request form can be given to implementing financial analyst.

- Application and document compliance with requirements of financing already received officer, noted in incoming mail and delivered to the branch manager for disposition.

- Conducting interviews with the applicant related to the financing plan and the correctness of the data document.

- Supporting Data Collection Request, both financial and non-financial:

- BI Checking (Debtor Information System)

- Blacklist Towing blank checks and BG

- Trade Checking / Market Checking / Business Checking to know the character and capabilities of third parties relating to the business customers' customers as business partners, suppliers, customers, business associations or professional organizations are the same as the customer's business. The results of this Checking Trade is a proven capability in running the business. Analysts prepare minutes of trade checking as documentation of the results of trade checking is done.

- Observing financial transactions conducted through accounts at Bank of Central Java Sharia and other banks.

\footnotetext{
${ }^{10}$ Islamic Bank of Central Java Financing
} 
Volume 7 Issue 2, June 2020

Nationally Accredited Journal,

Decree No. B/4130/E5/E5.2.1/2019

- Doing visits (OTS) to the location of the customer's business and taxation guarantees.

- Complete reports of visits to locations with pictures or photographs of the location of the business, products, machines used, and the atmosphere of the factory layout or place of business. Ask for proof of visit such as the customer's signature on a letter of assignment OTS.

- In order to guarantee taxation assessment refers to the applicable provisions, namely Shariah Financing Collateral BPP. And to determine the other supporting information.

- Analysts Process Financing:

- Perform cost analysis based 5C and business prospects, performance and ability to pay, as well as risk analysis using KKMR.

- Pouring analysis of financing in the form of the Proposed Financing.

- Proposes financing processed according to officials of the authority financing breaker force in Islamic Bank of Central Java.

- The process of checking by Admin Funding. Admin officer checked through a checklist form on the completeness of the application documents and document analysis, namely:

- Application documents: all documents are filled with customers, include: the legal aspects of the applicant, business agreements, documents and financial data, proof of ownership of collateral, and other supporting documents.

- Document Analysis: completeness of all documents created by the Bank or analyst Proposed Financing for material preparation, include: Results BI Checking and verification result DHN; The report on the business results of checking; Letter of Assignment on the judicial guarantees customer OTS; Assessed report assurance and customer business visit

Admin officer shall verify the correctness of the information presented in these documents, as evidence has been verified, admin officer should initials on those documents prior to submission as a proposed financing by financing section.

- Committee recommendations pebiayaan

- Each financing proposal which is the limit of Sharia Branch must be known and get recommendations from the finance committee, which consists of the Deputy Branch Manager, Head of Finance, Head of TSI and Accounting, Head of Marketing and Head of Supervision.

- If the ceiling above the financing authority Sharia Branch, then made a proposal to the Central Office in this case Divisit Sharia for approval.

- Issuance of Notice of Approval of Financing (SP4).

Under the financing agreement by Pincab, Semarang Branch Office publishes SP4 to the applicant. As a form of approval of the application for financing, the customer / applicant signed SP4. SP4 briefly covers the contents of information:

- Financing structure given.

- Terms of signing the Agreement.

- Disbursement Term Financing.

- Terms others.

- Signing of Financing Agreement, binding Security and Disbursement Financing.

- Agreement financing can be either notarized or under the hand. If the contract shall be notarized, then you should use Java notaries Islamic Bank partners that understand engagement by sharia law (a certified sharia). Agreement under 
hand applied to financing for customers who already cooperating agencies working place (MoU) with Bank Central Java Islamic system through the treasurer's salary through that agency. While notarized used for customers to use collateral in the form of fixed assets.

- Financing contract, signed by the applicant and husband / wife to individuals, Director / Head where customers work when the client business entity, other persons required to participate under the terms of the signature.

- Binding Security, implemented in accordance with: Guarantees on behalf of the individual owner of the husband or wife along to signing binding guarantees on the deed; Guarantees on behalf of business entities, signed by the board.

- Financing Realization:

Financing documents researched apparatus, when it is complete then the realization process implemented by the Finance Admin Officer.

\subsection{The role of the Notary Deed Making Murabahah in Islamic Bank of Central Java}

Notary is a public official only authorized to make authentic deeds, on all deeds, agreements and determination required by a general rule or by the concerned desired to be stated in an authentic deed, ensure certainty the date, save deed, and provide groose, copies and excerpts all along the deed was by a general rule not also be assigned or excluded to the official or other person designated by the Act. ${ }^{11}$

The relationship Notary on Islamic Financial Institutions (LKS) For an agreement to get the force of law, it must be registered before a notary. Therefore, every business including the Islamic business, always need a Notary as the official who made the authentic act in accordance with the duties set out in the Law of the Republic of Indonesia Number 30 of 2014 concerning the notary office. In addition, the notary is also authorized to provide legal advice to clients in order to achieve a high awareness of the law, namely to realize and appreciate the rights of the contracted obligations to the transaction before a notary was not legally flawed. ${ }^{12}$

Preparation of written agreements would also be very useful by disputes arise in the future so that there evidence tool on any dispute that occurred. ${ }^{13}$

In accordance with the task Notary to create an authentic deed in accordance with the Law of the Republic of Indonesia Number 30 of 2014 on Notary office. The role of the Notary in the Deed of Murabahah manufacturing operations in Islamic Bank of Central Java is giving legality (legally binding), which made a contract / agreement of Fiduciary, Power of Attorney Imposing Mortgage (SKMHT) and Deed Granting Mortgage (APHT).

\section{Closing}

\subsection{Conclusion}

Based on the above results, it can be concluded as follows:

\footnotetext{
${ }^{11}$ Adil, 2011, Mngenal Notaris Sharia, PT Citra Aditya Bakti, Bandung, p.12

${ }^{12}$ Ibid, p. 85-86

${ }^{13}$ Abdul Ghofur Anshori, 2007, Perbankan Sharia di Indonesia, Gadjah Mada University Press, Yogyakarta, p. 61-62
} 
Volume 7 Issue 2, June 2020

Nationally Accredited Journal,

Decree No. B/4130/E5/E5.2.1/2019

- Forms of Financing Islamic Bank consists of three categories, differentiated by the intended use, namely, the principle of trading financing, lease financing with principles, and financing with the principle of profit sharing.

- The procedure to be performed when going to Murabahah in Islamic Bank of Central Java is the customer comes to the bank and fill out application for financing. Then the application request is processed by our team of analysts and submitted to the Branch. After being processed in the bank, there will be interviews with the applicant and the supporting data collection request. However analyst team visits to the designated location and the applicant will be processed to admin financing for checking. If approved, there would be the signing of the financing agreement, the binding guarantees and financing disbursement.

- That the authorities make an authentic deed is a notary public, with the exception of the authority handed over to officials of another or others. Notary acts insofar related to the deed that made (Article 1 of Act No. 2 of 2014 on Notary), notary acts along the people, for the benefit of whom the deed was made (Article 20 of Act No. 2 of 2014 on Notary), notary plays throughout the place, where the deed was made (Article 18 of Act No. 2 of 2014 on Notary) and notary acts along the locus deed it (Article 19 of Act No. 2 of 2014 on Notary).

\subsection{Suggestion}

After doing this study the authors to provide input in the form of suggestions that are beneficial to all parties involved in the research, the authors suggest:

- As Islamic Banking, Islamic Bank Java should remain consistent with the provisions of sharia and law/rule/regulation applicable so that financing is going well and safe, should pay more attention completeness financing requirements which should have been completed by the candidate receiving the financing so there are no mistakes prior to the disbursement of financing such as file requirements needed in particular security documents. And still perform appropriate surveillance procedures to avoid financing problems

- Notary expected to meet Islamic principles that can pour in deed of agreement shar'i ideas, able to understand the legal facts and legal principles of Islamic economics in any contract or engagement occurs in the practice of Islamic banking.

\section{References}

\section{Book}

[1] Adil. 2011. Mengenal Notaris Sharia: PT. Citra Aditya Bakti.

[2] Anshori, AG, 2007. Perbankan Sharia di Indonesia. Yogyakarta: Gadjah Mada University Press.

[3] S, LA 2015. Notaris dan Penegak Hukum Oleh Hakim. Yogyakarta: Deepublish.

[4] Waluyo, DR, 2013. Hanya Ada Satu Jabatan Umum Ialah Notaris. Bandung: Notary Journal.

[5] Yuspin, W. 2007. Penerapan Pinsip Sharia dalam Pelaksanaan Agreement Murabahah. Surakarta: Journal of Legal Studies.

\section{Regulation}

[1] Act No. 30 of 2004 on on Notary 


\section{JURNAL AKTA}

eISSN : 2581-2114, pISSN: 2406-9426

[2] Article 1 paragraph 7 of Act No. 21 of 2008 on Islamic Banking

Etc

Islamic Bank of Central Java Financing 